The main topic discussed was the changing position of the Chief and the type of leadership emerging in towns. Dr. T. C. Mitchell, Director of the Institute, presented a paper on 'The Conflict of Roles in Intercalary Statuses', illustrated from the position of the African Chief who, under a system of indirect rule, occupies an intercalary status between the Administration and the people. Other papers discussed the co-existence of political organizations in Lusaka, the system of government of the African urban area of Bulawayo, the standard of living of Africans in the copper belt, the structure of authority in a mining district (Luanshya). An analysis of ritual symbols at various levels of interpretation, a study of the Chief in relation to the Administration, and of the emergence of leadership among the Lakeside Tonga, all gave rise to discussions in which the main theme of the Conference was elaborated. The last day of the Conference was devoted to discussion of the proposed symposium on 'The Industrial Revolution in British Central Africa'.

\title{
Program of African Studies: Northwestern University
}

AMERICaN interest in African studies is now both widespread and intense, but its rapid growth dates from the post-war years. At Northwestern University interest in Africa has been active since 1927 , being then mainly associated with the department of Anthropology directed by Professor Herskovits; a grant to the University from the Carnegie Corporation of New York has made possible a greatly expanded program of studies which was initiated in 1949 by an interfaculty seminar on Contemporary Africa. Speakers at the seminar included, besides members of the different faculties at Northwestern, United States Government officials, members of the United Nations and representatives of Colonial powers. A report by Professor Herskovits on the work of the program during the last five years describes the courses of study pursued, the development of the library, which now includes more than 8,000 volumes, as well as maps, music recordings, and collections of African art, and the field researches carried out by students. The holding of inter-faculty seminars has continued to be a feature of the program, and thereby has secured the co-operation of the various departments. The report envisages, in the future, the publication of monographs as well as a microfilming program to make available the results of field researches.

\section{Graduate Study Program on Contemporary Africa}

THE School of advanced international studies, Johns Hopkins University, Washington, D.C., held a summer session from 25 June to 25 August 1954 on Contemporary Africa. Speakers included Dr. Vernon McKay, of the School of Advanced Studies, Dr. H. A. Wieschoff, Mr. Kenneth Robinson, of the Oxford Institute of Colonial Studies, Miss Peter Ady, Professor Keppel-Jones of Queen's University, Canada. Among the subjects discussed were race relations, economic trends, British, French, Belgian, and Portuguese Africa.

\section{International Committee on Christian Literature for Africa}

THE International Committee (now known as ICCLA) celebrated the 25 th anniversary of its foundation by a dinner at the Royal Empire Society, London, on 8 October 1954. The Rev. T. A. Beetham, Africa Secretary of the Methodist Missionary Society and Chairman of ICCLA, presided. Speeches were made by the Rev. H. D. Hooper, former Chairman, and Dr. Wilson, first Chairman, as well as by Mr. G. Wilson of the Rhodesia and Nyasaland Publications Bureau and Mr. Peter Abrahams, the South African author. Most of the speakers dwelt on the work done for Africa by Margaret Wrong, to whose vision and enthusiasm the Committee owed its existence, who had, till her death, served it as its secretary, and who was still its inspiration. Mr. Abrahams made an urgent plea for the foundation of a newspaper, written for Africans by Africans and treating of current topics from a Christian standpoint. 